\title{
Acute myocarditis in a West Indian Manatee, Trichechus manatus (Sirenia: Trichechidae), from Puerto Rico
}

\author{
D.P. Moore ${ }^{1}$, E.H. Williams, Jr. ${ }^{2}$, A.A. Mignucci-Giannoni ${ }^{3}$, L. Bunkley-Williams ${ }^{4}$, F.E. Tippett ${ }^{5}$, \\ \& R.A. Montoya ${ }^{3}$ \\ 1. Caribbean Center of Marine Studies, Veterinary Clinic - Clinica Veterinaria, P.O. Box 585, Lajas, Puerto Rico \\ 00667-0585 \\ 2. Caribbean Aquatic Animal Health Project, Department of Marine Sciences, University of Puerto Rico, P.O. Box 9013, \\ Mayagüez, Puerto Rico 00861-9013; ewilliams@uprm.edu \\ 3. Red Caribeña de Varamientos - Caribbean Stranding Network, P.O. Box 361715, San Juan, Puerto Rico 00936-1715 \\ mignucci@caribe.net \\ 4. Department of Biology, University of Puerto Rico, P.O. Box 9012, Mayagüez, Puerto Rico 00861-9012; \\ lwilliams@uprm.edu \\ 5. Department of Pathology, Tuskegee University, School of Veterinary Medicine, Tuskegee, AL 36087; \\ ftippett@tuskegee.edu; Corresponding author; Potreen@coqui.net
}

Received 15-VII-2007. C Corrected 10-IX-2007. Accepted 13-II-2008.

\begin{abstract}
A 12-year old, adult male, West Indian Manatee, Trichechus manatus, which stranded in Ponce, Puerto Rico 26 August 1992, died from cardiac failure. Suppurative epicarditis, myocarditis and endocarditis with mild to moderate degeneration and necrosis was caused by an unidentified infectious agent. Moderate to heavy parasite respiratory infections with Cochleotrema cochleotrema and intestinal infections with Chiorchis groschafti and stomach infections with Heterochelius tunicatus probably contributed to the physiological compromise of the host's condition. This case represents the first record of a diagnosed natural mortality in the Antillean Manatee from the Caribbean and the first attributed to cardiac failure. Rev. Biol. Trop. 56 (Suppl. 1): 277-283. Epub 2008 May 30.
\end{abstract}

Key words: Natural mortality, suppurative epicarditis, myocarditis, endocarditis, Cochleotrema cochleotrema, Chiorchis groschafti, Heterochelius tunicatus.

The West Indian Manatee, Trichechus manatus Linnaeus is an herbivorous marine mammal found in coastal marine and fresh water and is an endangered species throughout its range in the Caribbean. Manatee mortality assessment has been documented in Florida since 1975. Studies on manatee mortality in Florida have been successful in documenting causes of death, identifying diseases and genetic conditions affecting the species, monitoring the impact of debris and pollution on manatee mortality, describing the parasite fauna affecting the species, analyzing watercraft-related mortality and propeller wounds as a cause of death, and age and reproductive biology (O'Shea et al. 1985, 1991, Ackerman et al. 1995, Wright et al. 1991, 1995). Although, the manatee is the most common marine mammal found dead in Puerto Rico, comprising $40.9 \%$ of all marine mammal mortality records (Mignucci-Giannoni 1990, Mignucci-Giannoni et al. 2000), little is known about the factors causing natural mortality. Between 1990 and 1995, the average number of death cases per year was six, increasing an average of $8.3 \%$ each year (Mignucci-Giannoni 1990, Mignucci-Giannoni et al. 2000). We describe the gross and histopathological findings of a necropsy of a stranded, wild West 
Indian Manatee that succumbed to cardiac failure. Mignucci-Giannoni et al. (2000) mentions this mortality, but did not describe it.

\section{MATERIALS AND METHODS}

An adult West Indian Manatee was reported stranded by a local fisherman in Barrio Mercedita, Sector La Esperanza, Ponce, Puerto Rico $\left(17^{\circ} 59.0^{\prime} \mathrm{N}, 66^{\circ} 35.4^{\prime} \mathrm{W}\right)$ on the morning of 26 August 1992. The animal was rolling in the subtidal shore attempting to breath, but was reported to have died soon afterwards. The case was designated CSN catalogue number NEPST194 and transported to the Caribbean Stranding Network (CSN) necropsy facility on Magueyes Island off La Parguera, Puerto Rico, at the Magueyes Island Laboratories of the Department of Marine Sciences, University of Puerto Rico at Mayagüez, and a complete necropsy was preformed on the fresh carcass following the protocols of Bonde et al. (1983) and Geraci and Lounsbury (1993). Digenea were fixed and preserved in steaming 5\% formalin, stained in Harris' hematoxylin, dehydrated, cleared in beech-wood creosote, mounted in Canada balsam, and identified with Beck and Forrester (1988) and Yamaguti (1971). Nematodes were relaxed in glacial acetic acid, preserved in 70\% ethanol, examined in glycerin, and identified with Sprent (1980) and Yamaguti (1961). Parasites were deposited in the U.S. National Parasite Collection, Beltsville, Maryland (USNPC). Tissue samples of the heart, lungs, liver, and intestine were collected and preserved in 10\% neutral-buffered formalin at a fluid to tissue ratio of 10:1 for histological examination. Tissue samples were prepared in $5 \mu \mathrm{m}$ paraffin sections stained in hematoxylin and eosin, Giemsa, Gram stain, or periodic acid-Schiff. Heart sections were also stained with bacterial-specific stains (BrownBren and Brown-Hopps) (Luna 1968). Stomach contents were rinsed in tap water over a 30-mesh $(0.52 \mathrm{~mm})$ screen to remove dirt and other fine particles that hamper microscopic examination. Stomach samples were preserved in 5\% formalin (Bonde et al. 1983) and prepared and examined following the methods of Hurst and Beck (1988) and Mignucci-Giannoni and Beck (1998). A modified microscope point technique (Hurst and Beck 1988) was employed to quantify the relative proportions of stomach contents. The complete skeleton was preserved, cleaned, and deposited in the University of Puerto Rico (Rio Piedras) Biology Museum (UPR BM MM0C042) (Mignucci-Giannoni et al. 1997).

\section{RESULTS}

The animal had no external lesions or significant scarring. Both flippers were freely movable and normal in appearance. Total length (straight line, snout to fluke) of the animal was $258 \mathrm{~cm}$, maximum girth $170 \mathrm{~cm}$, and weight $245 \mathrm{~kg}$. The animal was estimated to be approximately 12 years of age based on 12 growth layer groups in one of the ear bones from the skull (Marmontel 1993). An adequate nutritional status was indicated by the ventral outer and inner blubber thickness (32 and $20 \mathrm{~cm}$, respectively). Stomach contents $(67.0 \%$ unidentifiable rhizomes, $12.0 \%$ Halodule sp., 14.2\% Thalassia testudinum, 6.4\% Syringedium filiforme) were normal for this species in Puerto Rico with the exception of a slightly smaller percentage of $T$. testudinum (Mignucci-Giannoni and Beck 1998).

Moderate numbers of the opisthotrematid trematode, Cochleotrema cochleotrema (USNPC 78642) were found in the nares, larynx, trachea, bronchi, and bronchioles. Both lungs had generalized congestion. Eighty percent of the anterior mucosa of the colon was covered with the paramphistid trematode, Chiorchis groschafti (USNPC 78643). A heavy mucoid layer intermixed with the ascarid nematode, Heterochelius tunicatus (USNPC 78641) covered the mucosa at the duodenal diverticulum and anterior jejunum. Several nematodes were also free in the gastric lumen.

The most significant gross pathological findings were the presence of approximately 21 of yellow transudate in the peritoneal cavity and variably sized pale areas of necrosis throughout 
the myocardium. The pericardial sac contained approximately $100 \mathrm{ml}$ of clear transudate. Numerous ecchymotic and petechial hemorrhagic foci were present in the mediastinum, pericardium, epicardium, and over the serosal surface of the small intestines (Fig. 1).

Microscopically, the myocardial interstitium was diffusely infiltrated with abundant heterophils and minimal lymphoid cells that effaced myocardial fibers. Many of the myocardial fibers had numerous, closely spaced vacuolations throughout, while others were markedly eosinophilic and homogenous with loss of the characteristic cross striations. The pulmonary interstitium was diffusely congested with occasional alveolar spaces containing an eosinophilic, homogenous material consistent with a proteinaceous edema. There was generalized hepatocellular vacuolations-fat/glycogen. A few hepatocytes had an intracytoplasmic brown-green, grandular material, possibly bile. Kupffer's cells were engorged with a similar material and the surrounding sinusoids contained small numbers of heterophils. There was perivascular hemorrhage and proteinaceus edema fluid mixed with numerous heterophils and a small number of lymphoid cells in the epicardial layer. Similar inflammation extended into the endocardium.

\section{DISCUSSION}

The most serious lesions were in the heart. Suppurative epicarditis, myocarditis, and endocarditis with mild to moderate degeneration and necrosis were present (Fig. 5). No specific infectious agent was identified with the use of special stains; however, bacterial or other infectious agents were suspected because of the abundance of inflammatory cells and other pathological characters of the lesions (Fig. 2-5).

Little is known about infectious agents in wild West Indian Manatees and specific diagnostic tests have not been developed (Wetzold

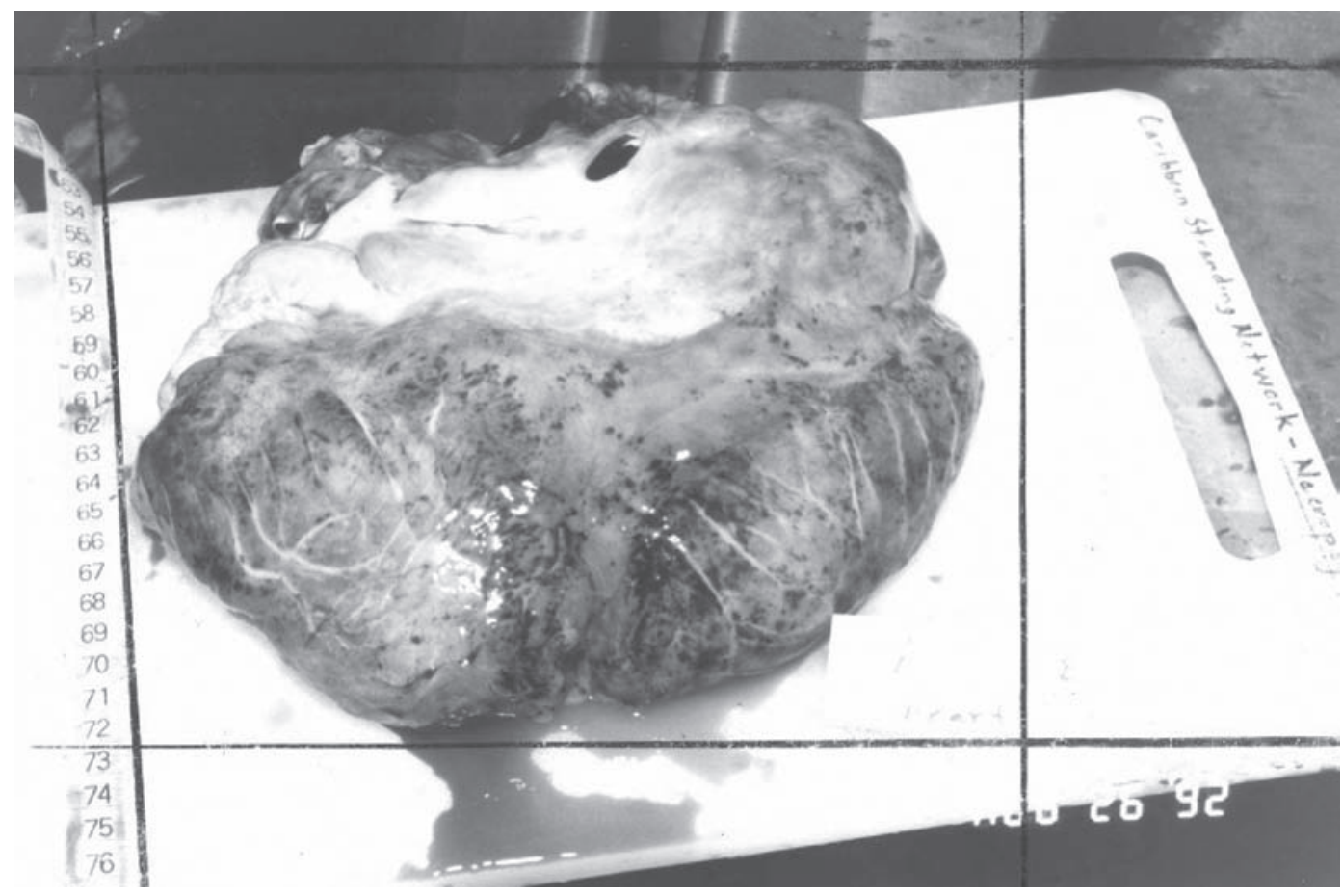

Fig. 1. Ventrodorsal aspect of the heart of a West Indian Manatee (\# NEPST194) showing numerous echymotic and petechial hemorrhagic foci of the epicardium and myocardium. Maximum length of the organ is $24.2 \mathrm{~cm}$. 


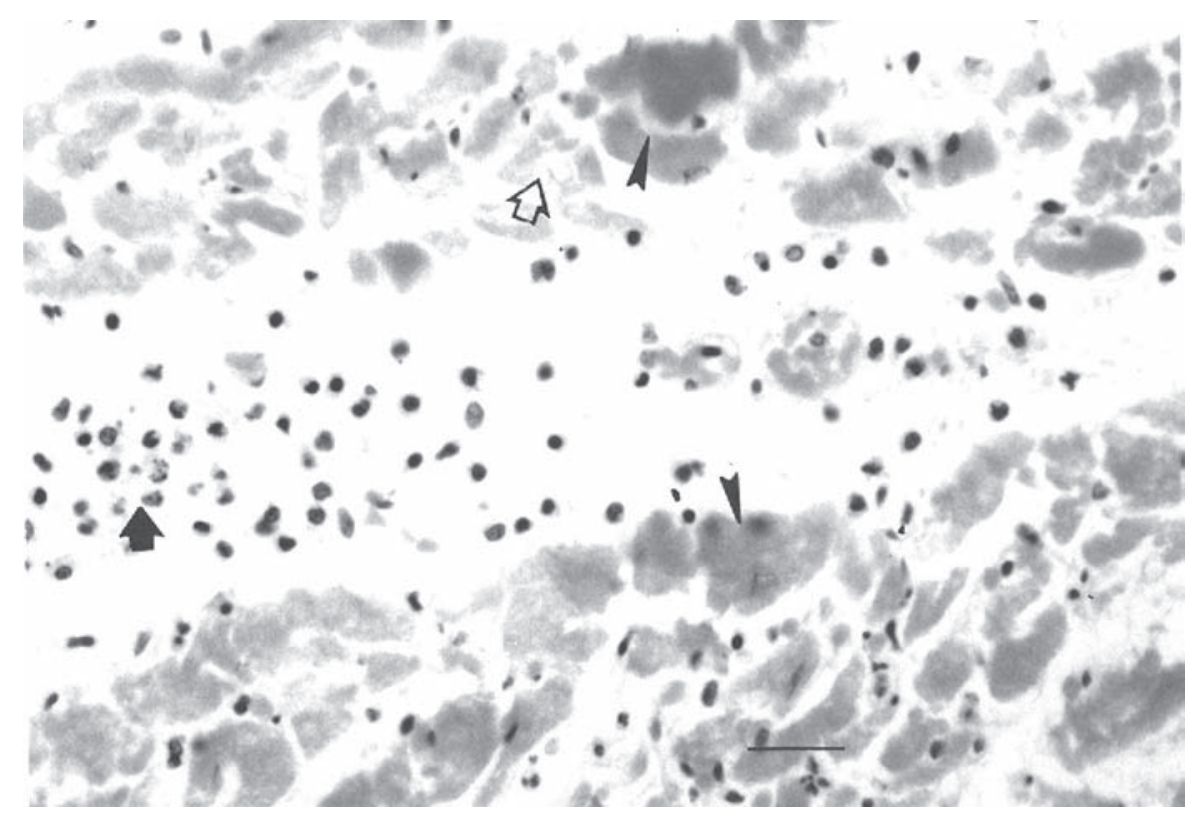

Fig. 2. Photomicrograph of a section of myocardial lesion from a West Indian Manatee (\# NEPST194) with suppurative myocarditis, epicarditis, and endocarditis. Notice the interstitial accumulation of inflammatory cells (large solid arrow), myocardial fiber hyalinization (arrowheads), and vacuolation with fragmentation (large open arrow). Hematoxylin and eosin stain. Bar $=28 \mu \mathrm{m}$.

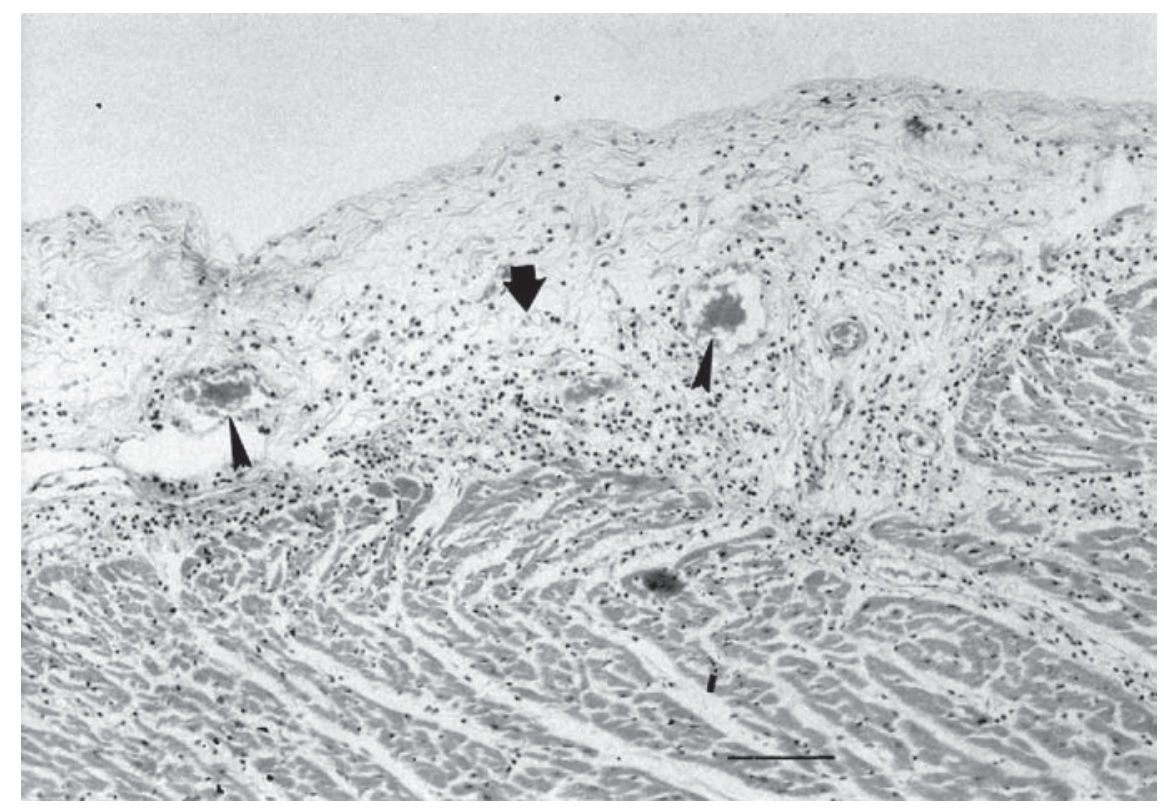

Fig. 3. Photomicrograph of a section of epicardium and subjacent myocardium from a West Indian Manatee (\# NEPST194) with suppurative myocarditis, epicarditis, and endocarditis. Notice the expansion of the epicardium with edema and inflammatory cells (large arrow) and a few congested blood vessels (arrowheads). Hematoxylin and eosin stain. Bar $=550 \mu \mathrm{m}$. 


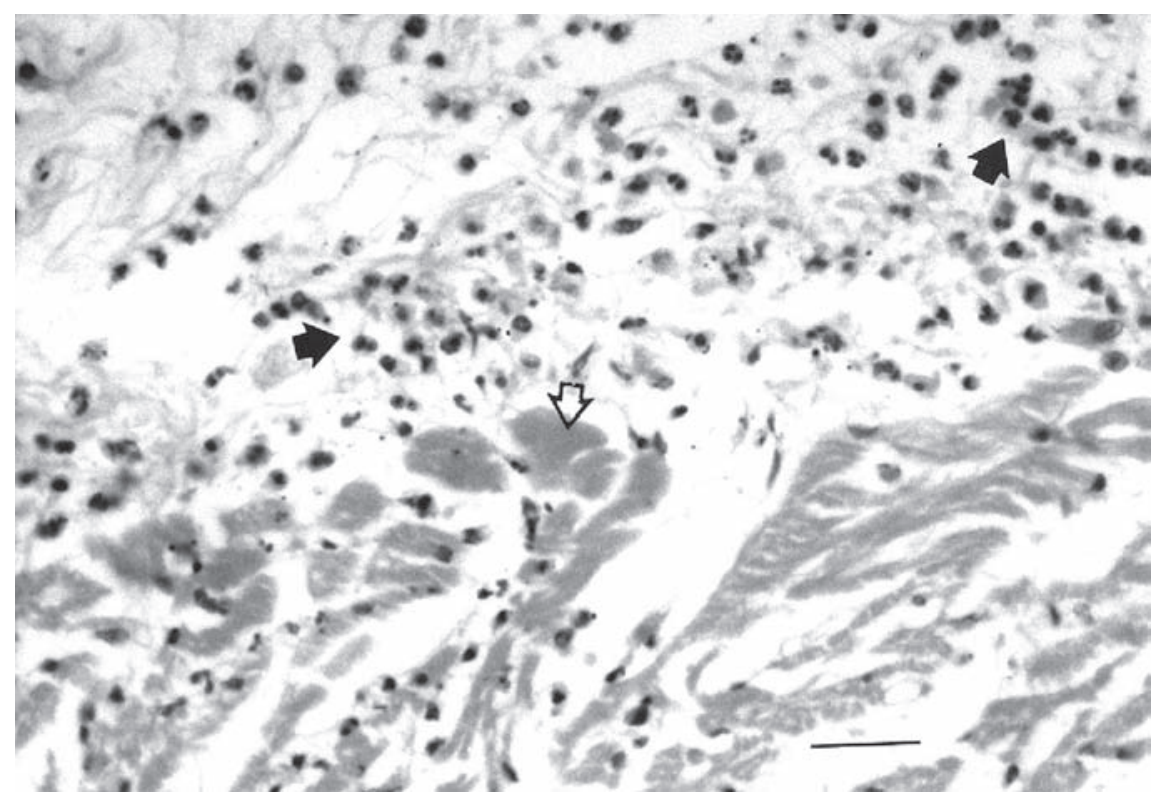

Fig. 4. Photomicrograph of a section of epicardium and subjacent myocardium from a West Indian Manatee (\# NEPST194) with suppurative myocarditis, epicarditis, and endocarditis. Notice the dense accumulation of heterophils within the epicardium (large solid arrows) and hyalinization of subjacent myocardial fibers (large open arrow). Hematoxylin and eosin stain. Bar $=28 \mu \mathrm{m}$.

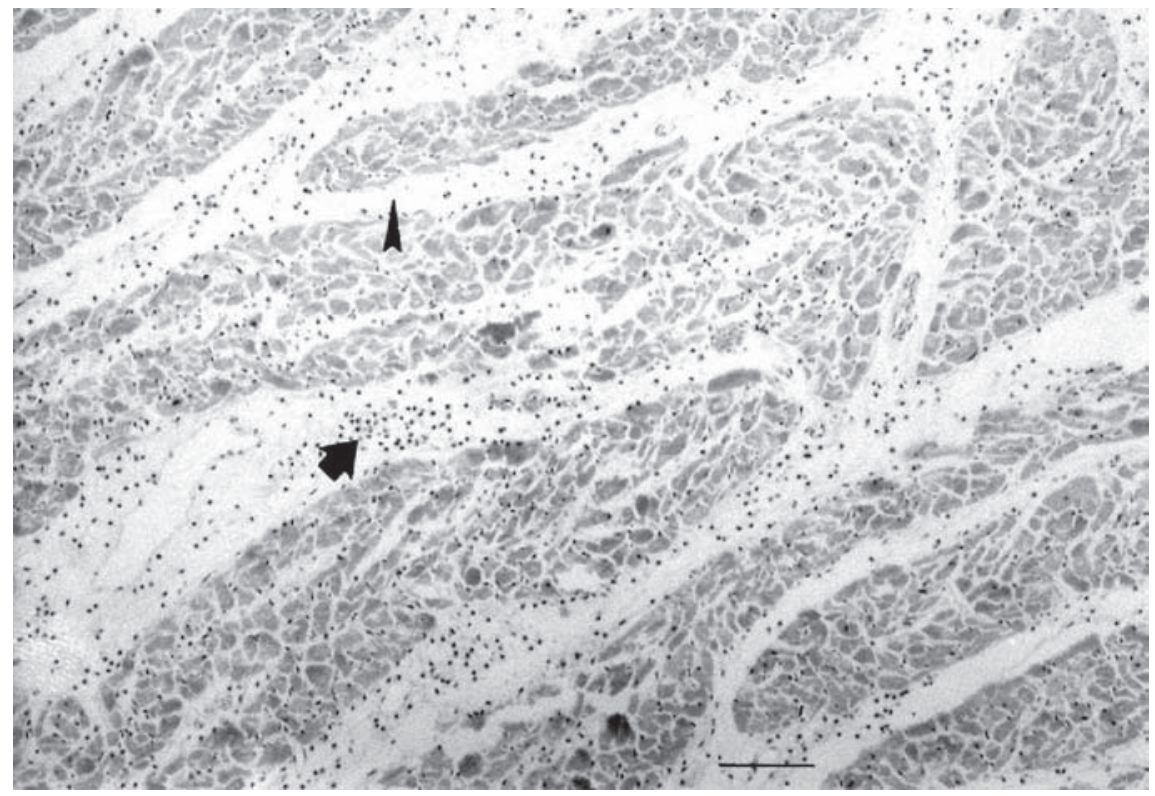

Fig. 5. Photomicrograph of a section of myocardial lesion from a West Indian Manatee (\# NEPST194) with suppurative myocarditis, epicarditis, and endocarditis. Notice the accumulation of interstitial areas with edema (arrowhead) and inflammatory cells (large arrow). Hematoxylin and eosin stain. Bar $=550 \mu \mathrm{m}$. 
et al. 1994). The gross and microscopic abnormalities in the heart were sufficiently extensive to attribute death to heart failure. The accumulation of fluids was probably secondary to heart failure. The moderate to severe parasitism probably added to the physiological stress induced upon the animal by the probable infectious agent. The respiratory parasite, C. cochleotrema, has been reported to occur commonly in the manatee from Florida (Beck and Forrester 1988), Puerto Rico (Mignucci-Giannoni et al. 1999a) and the Dominican Republic (MignucciGiannoni et al. 1999b), and Chiorchis spp. are abundant in manatees worldwide (Sprent 1980, Beck and Forrester 1988), including Puerto Rico (Mignucci-Giannoni et al. 1999a) and the Dominican Republic (Mignucci-Giannoni et al. 1999b).

Sweat and Wright (1994) reported valvular endocarditis in a stranded, wild, 16 to 17 year old, pregnant adult female Florida Manatee. Their description of the microbiological conditions associated with their case was limited due to the remote site and inability to collect culture samples. They concluded that the disease condition was caused by an unidentified bacterial infection, and suggested the added stress of pregnancy killed the female. Since the animal was not completely fresh, no examination for associated parasites, which seemed to play a role in our case, was possible. Similar heartvalve problems have been reported from manatees in Florida with some frequency (Buergelt et al. 1984, 1990, S.D. Wright, Fla. Mar. Res. Inst., pers. comm., 1996). Cold Stress Syndrome can cause myocardial degeneration in manatees in Florida, but many other disease factors are also involved (Bossart et al. 2003). Heart disease in wild West Indian Manatees may be more common than previous records would suggest.

Many carcasses of manatees are too decomposed to determination the cause of death (Bonde et al. 1983, Buergelt et al. 1984, O'Shea et al. 1985, Mignucci-Giannoni et al. 2000), and in Puerto Rico $33.7 \%$ of the manatee cases were obtained in a state of moderate to advanced decomposition (Mignucci-Giannoni et al. 2000).
This case is the first natural mortality diagnosed in the West Indian Manatee in the Caribbean and the first attributable to cardiac failure in Puerto Rico and the Caribbean.

\section{ACKNOWLEDGMENTS}

Manatee carcass salvage and specimen collection were conducted under U.S. Fish and Wildlife Service (USFWS) permits PRT 2-8430 and PRT -684532 and under yearly permits from and a cooperative agreement with the Puerto Rican Department of Natural and Environmental Resources. Partial support for this study was provided in grants from the Caribbean Field Office, USFWS, and Save the Manatee Club. We thank Cathy A. Beck, Sirenia Project, U.S. Geological Survey, for identifying and quantifying the stomach contents, and confirming our parasite identifications; M. Marmontel, Project Marimua, Brazil, for assistance in aging the manatee; CSN volunteers for general assistance; and R.K. Bonde, Sirenia Project, and S.D. Wright, Florida Department of Environmental Protection, for comments on the manuscript.

\section{RESUMEN}

El 26 de agosto de 1992, un manatí antillano, Trichechus manatus, macho, adulto, de 12 años de edad, murió de un fallo cardíaco mientras paseaba por Ponce, Puerto Rico. Presentaba epicarditis supurativa, miocarditis y endocarditis, con degeneración y necrosis de leve a moderada, causadas por un agente infeccioso no identificado. Las infecciones parasitarias respiratorias, de moderadas a graves, causadas por Cochleotrema cochleotrema, las intestinales, por Chiorchis groschafti, y las estomacales, por Heterochelius tunicatus, contribuyeron probablemente al compromiso fisiológico del hospedero. Este caso representa el primer registro de muerte natural diagnosticada en un manatí del Caribe y el primero atribuido a un fallo cardíaco.

Palabras clave: muerte natural, epicarditis supurativa, miocarditis, endocarditis, Cochleotrema cochleotrema, Chiorchis groschafti, Heterochelius tunicatus.

\section{REFERENCES}

Ackerman, B.B., S.D. Wright, R.K. Bonde, D.K. Odell \& D.J. Banowetz. 1995. Trends and patterns in mortality of manatees in Florida, 1974-1992, p. 223-258 In T.J. 
O'Shea, B.B. Ackerman, \& H.F. Percival (eds.). Population biology of the Florida Manatee. Nat. Biol. Serv. Inform. Tech. Rept. 1.

Beck, C.A. \& D.J. Forrester. 1988. Helminths of the Florida Manatee, Trichechus manatus latirostris, with a discussion and summary of the parasites of sirenians. J. Parasitol. 74: 628-637.

Bonde, R.K., T.J. O'Shea \& C.A. Beck. 1983. Manual of procedures for the salvage and necropsy of carcasses of the West Indian Manatee (Trichechus manatus). National Technical Information Service, Springfiels, Virginia, USA.

Bossart, G.D., R.A. Meisner, S.A Rommel, S-J. Ghim \& A.B. Jenson. 2003. Pathological features of the Florida Manatee Cold Stress Syndrome. Aquat. Mamm. 29: 9-17.

Buergelt, C.D., R.K. Bonde \& C.A. Beck. 1984. Pathological findings in manatees in Florida. J. Amer. Med. Assoc. 185: 1331-1334.

Buergelt, C.D., R.K. Bonde, C.A. Beck \& T.J. O’Shea. 1990. Myxomatous transformations of the heart valves in Florida Manatees. J. Zoo Wildl. Med. 21: 220-220-227.

Geraci, J.R. \& V.J. Lounsbury. 1993. Marine mammals ashore: A field guide for strandings. Sea Grant, TAMU-SG-93-601.

Hurst, L.A. \& C.A. Beck. 1988. Microhistological characteristics of selected aquatic plants of Florida. U.S. Fish Wildl. Serv. Biol. Rept. 88(18).

Luna, L.G. (ed.). 1968. Manual of histologic staining methods of the Armed Forces Institute of Pathology. McGraw-Hill, New York, New York, USA.

Marmontel, M. 1993. Age determination and population biology of the Florida Manatee. Ph. D. Thesis, University of Florida, Gainesville, Florida, USA. 313 p.

Mignucci-Giannoni, A.A. 1990. Mortality and stranding records of marine mammals in Puerto Rico and the Virgin Islands-1967-1989. Symp. Nat. Res. Puerto Rico 16: 211-271.

Mignucci-Giannoni, A.A. \& C.A. Beck. 1998. The diet of the manatee (Trichechus manatus) in Puerto Rico. Mar. Mamm. Sci. 14: 394-397.

Mignucci-Giannoni A.A., C.A. Beck, R.A. MontoyaOspina \& E.H. Williams, Jr. 1999a. Parasites and commensals of the West Indian Manatee from Puerto Rico. J. Helminthol. Soc. Wash. 66: 67-69.

Mignucci-Giannoni, A.A., R.A. Montoya-Ospina, N.M. Jiménez-Marrero, M.A. Rodríguez-López, E.H.
Williams, Jr. \& R.K. Bonde. 2000. Manatee mortality in Puerto Rico. Environ. Manag. 25: 189-198.

Mignucci-Giannoni, A.A., G.M. Toyos-Gonzalez, J. PerezPadilla, R.A. Montoya-Ospina \& E.H. Williams, Jr. 1997. First osteological collection of marine mammals for Puerto Rico and the Virgin Islands. Carib. J. Sci. 33: 288-292.

Mignucci-Giannoni, A.A., E.H. Williams, Jr., G.M. ToyosGonzalez, J. Perez-Padilla, M.A. Rodriguez-Lopez, M.B. Vega-Guerra, \& M. Ventura-Gonzalez. 1999b. Helminths from a stranded manatee in the Dominican Republic. Vet. Parasitol. 81: 69-71.

Moore, D. P., L. Bunkley-Williams, E. H. Williams, Jr., A. A. Mignucci-Giannoni, F. E. Tippett, R. A. Montoya \& W. G. Dyer. 2007. Successful surgical treatment of spear wounds in a Hawksbill Turtle, Eretmochelys imbricata; and cardiac failure of an Antillian Manatee, Trichechus manatus manatus, in Puerto Rico. Proc. Assoc. Mar. Labs. Carib. 33: 93.

O’Shea, T.J., C.A. Beck, R.K. Bonde, H.I. Kochman \& D.K. Odell. 1985. An analysis of manatee mortality patterns in Florida, 1976-81. J. Wildl. Manag. 49: 1-10.

O’Shea, T.J., G.B. Rathbun, R.K. Bonde, C.D. Buergelt \& D.K. Odell. 1991. An epizootic of Florida Manatees associated with a dinoflagellate bloom. Mar. Mamm. Sci. 7: 165-179.

Powell, J.A., D. Belisky \& G.B. Rathbun. 1981. Status of the West Indian Manatee (Trichechus manatus) in Puerto Rico. J. Mamm. 62: 642-646.

Rathbun, G.B., T. Carr, N. Carr \& C.A. Woods. 1986. The distribution of manatees and sea turtles in Puerto Rico, with emphasis on Roosevelt Roads Naval Station. Nat. Tech. Inform. Serv. PB86-151834/GAR.

Sprent, J.F.A. 1980. Ascaridoid nematodes of sirenianThe Heterocheilinae redefined. J. Helminthol. 45: 309-327.

Sweat, J.M. \& S.D. Wright. 1994. Valvular endocarditis in the Florida Manatee, Trichecus [sic] manatus: Gross and histopathological findings. Manatee and Dugong Research Conference, Gainesville, Florida, USA 1: 124-126.

Wetzold, M.D., J.L. Bradley, L.G. Green, P.A. Klein \& P.M. McGuire. 1994. Manatee serology: Development and specific reagents. Manatee and Dugong Res. Conf., Gainesville, Florida, USA 1: 131-133.

Yamaguti, S. 1961. Systema Helminthum. Volume III. The nematodes of vertebrates. Interscience, New York, New York, USA.

Yamaguti, S. 1971. Synopsis of digenetic trematodes of vertebrates. Volumes 1-2. Keigaku, Tokyo, Japan. 
